\title{
The Role of Auditing in the Fight Against Corruption
}

\author{
Klarskov Jeppesen, Kim
}

Document Version

Accepted author manuscript

Published in:

British Accounting Review

DOI:

10.1016/j.bar.2018.06.001

Publication date:

2019

\section{License \\ CC BY-NC-ND}

Citation for published version (APA):

Klarskov Jeppesen, K. (2019). The Role of Auditing in the Fight Against Corruption. British Accounting Review, 51(5), [100798]. https://doi.org/10.1016/j.bar.2018.06.001

Link to publication in CBS Research Portal

\section{General rights}

Copyright and moral rights for the publications made accessible in the public portal are retained by the authors and/or other copyright owners and it is a condition of accessing publications that users recognise and abide by the legal requirements associated with these rights.

Take down policy

If you believe that this document breaches copyright please contact us (research.lib@cbs.dk) providing details, and we will remove access to the work immediately and investigate your claim. 


\section{The Role of Auditing in the Fight Against Corruption Kim Klarskov Jeppesen}

Journal article (Accepted manuscript*)

Please cite this article as:

Klarskov Jeppesen, K. (2018). The Role of Auditing in the Fight Against Corruption. British Accounting Review. D0l: 10.1016/j.bar.2018.06.001

DOl: 10.1016/j.bar.2018.06.001

* This version of the article has been accepted for publication and undergone full peer review but has not been through the copyediting, typesetting, pagination and proofreading process, which may lead to differences between this version and the publisher's final version AKA Version of Record.

Uploaded to CBS Research Portal: March २०19

(C) 2019. This manuscript version is made available under the CC-BY-NC-ND 4.0 license

http://creativecommons.org/licenses/by-nc-nd/4.0/ 


\title{
The role of auditing in the fight against corruption
}

\begin{abstract}
The purpose of this paper is to analyze how various types of auditing may contribute to fight corruption. While previous literature has primarily addressed auditing's ability to prevent corruption, this paper systematically explores auditing's potential to detect corruption. It argues that financial auditing has excluded corruption from the definition of fraud and instead classified it as 'non-compliance with laws and regulations'. The main arguments for this exclusion is that corruption leaves no material errors in financial statements and no evidence for the auditor to follow. The paper refutes this, arguing that commercial and political corruption creates misstatements in the financial statements of the corruption giver's organization as well as the corruption receiver's organization. Thus, if auditing is to gain a more prominent role in the fight against corruption, auditing standards must include corruption in the definition of fraud, private and public sector auditors need to cooperate and exchange information, auditing techniques to detect corruption should be employed, and the auditing profession must embrace effective preventive measures such as anticorruption certifications.
\end{abstract}

Key words: Corruption, bribery, accounting, auditing, expectation gap, IFAC.

\section{Introduction}

Systemic corruption is generally seen as the primary obstacle to economic and political development in any country where it prevails. This is because corruption distorts economic incentives to invest, undermines public institutions, redistributes wealth and power to the undeserving, promotes asset stripping and the illegal export of resources and generates distrust within society (see e.g. Everett et al., 2007; Klitgaard, 2006; Rothstein \& Varraich, 2017). The World Economic Forum ${ }^{1}$ estimates that the cost of corruption is US\$ 2.6 trillion, which equals more than 5\% of global GDP, and that corruption increases the cost of doing business by up to $10 \%$ (see e.g. Thomson, 2017). The annual cost of bribery alone is estimated to around $2 \%$ of global GDP (IMF, 2016). Thus, there are good reasons for governments and business to increase the fight against corruption.

Auditing is considered one of the eight pillars of a national integrity system, which can protect against corruption (Dye and Stapenhurst, 1998). Auditors have a unique position within firms as 
public interest representatives, monitoring and reporting on an organization's compliance with established criteria. In addition, the scope and extent of auditing in society is increasing (Power, 1997). Auditors are therefore in a particularly good position to participate in the fight against corruption, in case this is required. However, the role of auditing in the fight against corruption has so far been hesitant. Auditors are from time to time accused of not detecting corruption, for instance in the latest FIFA ${ }^{2}$ scandal (Browning, 2015), and there appears to be an "expectation gap" (Porter, 1993) regarding the responsibility of auditing to detect corruption, at least in some parts of the world. While private sector financial auditing has generally neglected corruption as a potential source of material errors in financial statements, public sector auditing has, to some degree, accepted responsibility for the prevention of corruption (Dye and Stapenhurst, 1998). This paper examines the arguments for the limited role of auditing in combatting corruption and analyses the potential for auditing to play a more direct role in the fight against commercial and political corruption. A proactive role may reveal the level of corruption at the micro level of firms and organizations and thus force governments and business to react. It may also benefit the auditing profession itself by supporting its claim to work in the public interest and thereby strengthen its professional recognition by society. Auditing work to prevent and/or detect corruption also has the potential to become an important new service for the auditing profession. Consequently, there are good reasons to take a closer look at the potential role of auditing in the fight against corruption.

The paper proceeds in section 2 with a reviewing of the literature concerning the role of auditing in relation to corruption. The review provides an overview of the issue and argues that corruption has been excluded from the concept of fraud and is therefore generally disregarded by financial auditors as a source of material errors in financial statements. Section 3 then takes a closer look at some of the common arguments for not addressing corruption and discusses why these are partly wrong. The following sections 4 and 5 continue with an analysis of the potential role of auditing in the prevention and detection of corruption. Section 6 concludes and discusses future perspectives for research and practice.

\section{The exclusion of corruption from the concept of fraud}

There are many competing definitions of corruption (Johnston, 1996; Rothstein \& Varraich, 2017). The definitions used by accountants are usually what Johnston (1996) calls behaviour-focused: corruption is the abuse of public office, powers, or resources for private benefit. Accordingly, the 
International Organization of Supreme Audit Institutions (INTOSAI, 2013) defines corruption in the public sector as the abuse of public authority or trust for private benefit, while private sector corruption may similarly be defined as "an act in which a person uses his position to gain some personal advantage at the expense of the organization he represents" (Wells, 2014: 241). In a widely cited analysis of the elements of corruption, Klitgaard (1996) calls it the product of "monopoly power" plus "discretion" minus "accountability". It follows from the accountability part of this equation that accounting and auditing together play an important role in determining the level of corruption. Modern governance programmes, such as new public management, rely on discretion rather than hierarchical structure and bureaucracy to create flexible and responsive organizations (Power, 1997), but increased management discretion also gives rise to opportunities for corruption. The use of management discretion is therefore controlled by requiring management to demonstrate transparency and accountability by means of financial statements. As financial statements are by definition management assertions concerning economic reality, they cannot be trusted and need to be audited by an independent third party to provide assurance (Power, 1997). Thus, it is reasonable to expect that auditing will play an active role in constraining corruption. Dye and Stapenhurst (1998), for example, consider auditing to be one of the eight "pillars of integrity" that support a national integrity system ${ }^{3}$, while Shihata (1997: 18) from the World Bank calls for "effective systems of financial management, including serious and timely record keeping, auditing, and supervision of performance" as measures to curb corruption. Tanzi (1998: 575) from the IMF likewise argued that good auditing offices are necessary "to discourage or discover corrupt activities" and a recent study shows that firms with audited financial statements pay significantly lower amounts in bribes than non-audited firms (Farooq \& Shehata, 2018). Evidence from the public sector also suggests that audit independence and audit professionalism reduce a country's corruption level (Gustavson and Sundström, 2016). The same appears to be the case in the private sector, where the number of accountants per capita in general (Kimbro, 2002), the presence of Big-4 accounting firms in particular (Malagueño et al., 2010), and extensive financial reporting requirements and high litigation risk (Khalil et al., 2015) reduces the level of perceived corruption. However, accounting may also be misused to enable corruption. According to Neu et al. (2013), skilful use of accounting practices structure and enable corruption by constructing space for discretion, by enabling the lengthening of the transaction chain and allowing costs to be added in each link and by the fabrication of invoices that will make unusual accounting transactions appear normal. 
However, while the public may expect auditors to be active in the fight against corruption, they are more reluctant themselves. The debate concerning the auditing profession's responsibility in relation to the detection of corruption is not of recent origin. Brief (1977) pointed out that the issue was the subject of debate in the USA in the late 19th century, with "no unanimity of opinion" among accountants regarding the role of auditing. More than a century later, auditors are still reluctant to address corruption. In a discussion paper outlining the accounting profession's role in the fight against corruption, the International Federation of Accountants (IFAC) wrote that accountants' (including external auditors) responsibilities "cannot be expected to be primarily that of watchdogs against corruption or law enforcement officers" and also stated that "while it might be considered that accountants should report acts of corruption to external authorities, this would be an unreasonable burden without the requisite legal infrastructure being enacted, the equivalent obligations being placed on the other business professions and institutions, and the public being supportive of this requirement" (IFAC, 1999). Similarly, an inspection of major financial auditing textbooks shows that while auditors now generally acknowledge a responsibility to detect material fraud, they are reluctant to include corruption explicitly within the concept of fraud. In auditing textbooks, such as those of Eilifsen et al. (2014), Arens et al. (2014), Gray and Manson (2008), Hayes et al. (2005) and Soltani (2007), the issue of corruption is not discussed; indeed, the words “corruption" or "bribery" are not even found in the books' indexes. This may be because some authors consider fraud and corruption to be two different offenses (e.g. Labuschagne and Els, 2006). Whether this is the case obviously depends on the definition of fraud. ISA $240^{4}$ defines fraud as "an intentional act involving the use of deception to obtain an unjust or illegal advantage" (ISA 240, 11.), a definition that may well include corruption. Nevertheless, corruption is excluded from ISA 240 as pointed out by Kassem \& Higson (2016). It categorizes fraud into two types: asset misappropriation and fraudulent financial statements; with no discussion of corruption to be found except in section A5, in which kickbacks are briefly mentioned as an example of the misappropriation of assets. The consequence of excluding corruption from the definition of fraud is that private sector financial auditors are not expected to assess the risk of corruption when planning their audits. However, according to the corresponding ISSAI $1240,{ }^{5}$ public sector financial auditors are required to remain alert to the occurrence of abuse throughout the audit. Abuse is defined as "behavior that is deficient or improper when compared with behavior that a prudent person would consider reasonable and necessary business practice given facts and circumstances" and abuse includes "misuse of authority or position for personal financial interests or those of an immediate or 
close family member or business associate" (ISSAI 1240: 6). Thus, some types of corruption may fall within the definition of abuse and there are examples that public sector auditors employ to detect corruption (see e.g. Chowdhury and Innes, 1998; Liu and Lin, 2012), whether this is done in accordance with the ISSAI standards or not.

The exclusion of corruption from the ISA 240 definition of fraud is hardly unintentional. It differs from the categorization developed by Joseph Wells (2014) and the Association of Certified Fraud Examiners (ACFE), which defines three main categories of occupational fraud: asset misappropriation, fraudulent financial statements and corruption. Each of the three main types of fraud is subdivided into a number of distinct fraud schemes. In this model, there are four types of corruption: 1) bribery, for which the two subcategories are invoice kickbacks (a typical case being when a supplier bribes someone in the procurement function to get the order) and bid rigging, these being attempts to manipulate the competitive bidding process to ensure the preferred vendor wins the process; 2) conflicts of interest, usually found in the procurement function when someone makes purchases at inflated prices from a company in which he or she has interests; 3 ) illegal gratuities, constituting employees receiving a gift from a vendor, which is not directly dependent of an order or similar, in violation of company policy; 4) economic extortion, being bribery cases in which the employee initiates corruption by demanding kickbacks from the vendor for placing an order, or for granting some benefit, such as a loan, a permission or similar.

In line with the ACFE definition of fraud, internal auditors explicitly include corruption in their definitions of fraud (see e.g. ECIIA, 1999; Reding et al., 2013). However, only one external auditing textbook has adopted the ACFE fraud definition and explicitly discusses corruption as a distinct type of fraud (Gramling et al., 2012), while another briefly discusses bribery in the tendering process (Davies and Aston, 2011). Apart from these isolated cases, it appears that IFAC and the external auditing profession have decided to exclude corruption from their definition of fraud. Instead, several types of corruption are explicitly considered in ISA 250 (revised) ${ }^{6}$ and in the 2016 revisions to IFAC's Code of Ethics (IESBA, 2016) as examples of the client's noncompliance with laws and regulation. Non-compliance should lead the auditor to obtain an understanding of the circumstances, discuss the matter with management and based on this discussion, assess whether further action is needed. Further action may include disclosing the matter to appropriate authorities, which will not be considered a breach of the confidentiality duty. Thus, IFAC does not consider corruption to be fraud but rather non-compliance with laws, which in turn 
is a matter for the police to investigate and an ethical issue to consider for accountants in business (IESBA, 2016). The existence of an expectation gap regarding corruption, such as that reported in the FIFA case (Browning, 2015), is therefore either caused by deficient standards or by the public's unreasonable expectations (Porter, 1993), as argued by IFAC (1999). The following section takes a closer look at the explanations provided by the auditing profession concerning why it is an unreasonable expectation that it should actively search for and report on corruption.

\section{The arguments for not addressing corruption}

In theory, auditing may play two different roles in the fight against corruption: it may prevent or detect corruption. These roles are partly interrelated. If auditors detect corruption, this may also serve as deterrence and thus prevent further corruption, and if auditors prevent corruption, there will be less to detect. While Neu et al. (2014) conclude that the existing literature suggests that a combination of preventive and detective techniques is the best way to reduce corruption, the interest of previous research has almost solely been on the preventive side. Thus, the literature influenced by the auditing profession, clearly favours the preventive role. A general mantra, as stated by ISSAI 5700, is that "it is much better to prevent than detect corruption" (INTOSAI, 2013: 7). Dye and Stapenhurst (1998: 13-14) note that financial auditors see their role as being to deter corruption, not detecting it: "auditors in the private or public sector who have been trained to audit financial statements do not have a history of finding much fraud through their audits. Their main contribution to preventing corruption has been the strong psychological factor of deterrence". Reporting from the INCOSAI Congress in 1998, Borge (1999: 4) seconds this opinion and writes that "most SAIs believe that their main contribution as regards the prevention and detection of fraud and corruption lies in improving overall transparency and accountability, supporting an environment that limits the opportunity for acts of corruption”. Similarly, INTOSAI's present exposure draft for a standard regarding corruption is entitled "Guideline for the Audit of Corruption Prevention in Government Agencies" (ISSAI 5700) and does not cover the role of Supreme Audit Institutions (SAIs) in the detection of corruption, which is generally seen as a task for the police or other investigative agencies.

The reason for preferring the preventive role appears to be rather pragmatic: "experts agree that it is easier to prevent fraud and corruption than to detect it" (Borge, 1999: 12). A common rationale for this is that some auditors believe that corruption leaves no trail of evidence. For example, Khan (2006: 5) is of the opinion that auditors "can hardly detect or investigate into the actual event of 
corruption, since the culprits, generally, do not leave any documented evidence". The likelihood that transactions are not recorded leads Khan (2006: 27) to conclude: "The auditors cannot play a role in detecting corruption. However, they can help in preventing corruption by pointing out areas where opportunities for corruption exist". The problem of missing evidence is probably greatest in severe cases in which corruption has become systemic. Here Klitgaard (2006) argues that preventive measures, such as auditing, are easily circumvented or obstructed. Auditing against corruption is made difficult by an administrative chaos where information is not recorded; because auditors (e.g. auditor generals) may lose their independence and objectivity by being politically appointed; because lack of transparent administrative routines allows civil servants excessive discretion and provides no clear audit criteria; because the sanctions against corruption are weak, should it be detected by auditing; and because there is no political will to listen to auditors' recommendations and reform the public sector to prevent corruption. There are also examples of violent threats and even murders of critical auditors investigating corruption (Okike, 2004).

There are undoubtedly types of corruption that leave little evidence for an auditor to examine. One such type is political corruption, which some writers (e.g. Khan, 2006) consider to be outside an auditor's remit. Political corruption includes the practices of favouritism (political patrons favouring particular groups) and clientelism or nepotism (individuals or relatives respectively being favoured in return for their political, monetary, or cooperative support) (ISSAI 5700). While bribery and similar types of commercial corruption take place in horizontal networks between equally powerful actors with trust-based and intimate relationships, political corruption takes place in informal vertical networks. In these, the patron is more powerful than the client, but as the relationship is governed by the norm of reciprocity, the client will have to honour the patron with intangible assets, such as respect, subordination, loyalty and political favours (Jancsics, 2014). Thus, subordinates' desire to act in a way that pleases those in power or their identification with corrupt practices as a normative ideal constitute a central part of what makes corruption possible (Roberts, 2015). Political corruption is frequent in developing countries at the national and municipal level (Klitgaard, 2006), but may also occur in developed countries in the form of politicians renting out their ability to influence and shape the rules that determine how government is enacted, i.e. whether a programme is funded, a contract awarded, or tax exemptions granted in return for financial contributions (Neu et al., 2013). Cases of political corruption are difficult to detect for auditors because the link between the patron and the client is elusive and because the corrupt exchanges are intangible and/or hidden. Furthermore, politicians may directly interfere against auditors in cases in 
which they decide to investigate allegations of corruption (Sikka and Lehman, 2015), or they may simply control the appointment of auditors through systems of clientelism and nepotism. When discovering cases of political corruption, auditors therefore often rely on cooperation with the press to create awareness of the corrupt case and to force other investigative agencies to act (Dye and Stapenhurst, 1998).

Apart from the fact that some types of corruption leave little evidence for the auditor to follow, there are two other reported issues that may constrain auditors from looking for it. First, corruption is often actively organized to circumvent any attempts to prevent it by means of internal controls and audits. For organizational elites, the main resources for illegal exchange are control over critical resources, strategic decisions and large-scale contracts. The elites are often able to cover up their corrupt acts by "turning off” internal and external control systems (Jávor and Jancsics, 2016). To conduct an illegal exchange, elites need the help of the middle level of the organization, e.g. professionals who have the knowledge to cover up the illegal transactions and make them appear legal. In return, the organizational elites reward middle level managers, for instance through the formal incentive system or by accepting middle level management's own corruption (Jávor and Jancsics, 2016). In addition, auditors are sometimes found to participate in such corrupt networks, examples being Mennicken's (2010) report of Russia's “black auditors” and Okike's (2004) and Bakre's (2007) reports of corruption within the accounting profession in Nigeria. Second, the level of corruption is partly determined by culture (Kimbro, 2002) and in a local culture certain types of corruption may be seen as acceptable and normal. East Asian accountants, for instance, do not view bribes and illegal gratuities as seriously as accountants from other areas of the world (Bierstaker, 2009). Another example is a common redefinition of corruption as acceptable "facilitative payments". For example, in 2011 the Carlsberg Breweries publicly stated that although it was a clear business policy to avoid bribery, facilitative payments were accepted as a necessary evil to do business in certain markets. ${ }^{7}$ However, in 2015 Carlsberg changed this policy and now does not tolerate facilitating payments at all, even if the consequence is that Carlsberg loses business. ${ }^{8}$ The reason for this policy change is likely to be rooted in the British Bribery Act of 2010, which allows the prosecution of companies with links to the UK, regardless of where the corrupt act has occurred. Thus, accountants and auditors in some cases appear to turn a blind eye to certain types of corruption. 
To sum up this section, the literature suggests that it may be difficult for auditors to prevent and detect political corruption because the exchange of intangible assets leaves little tangible evidence. However, this is not the case for most types of commercial corruption, which involves exchanges of tangible assets that are likely to leave a trail of evidence for the audit to follow. Nevertheless, external auditors only reluctantly accept a preventive role and hardly ever a detective role. The two following sections will take a critical look at how auditing may prevent respectively detect corruption.

\section{How auditing may prevent corruption}

COSO Enterprise Risk Management (COSO, 2004) focuses on the management of four main types of risk: strategic risk, operational risk, compliance risk and reporting risk. Compliance risk is the risk that a company is not in compliance with laws and regulations. To the extent that corruption is illegal, enterprises are therefore expected to manage the risk of engaging in corrupt practices. This may be done by identifying the areas in which corruption may occur, assessing the likelihood and impact of such corruption and establishing and monitoring internal controls to prevent corruption. Table I outlines some of the common types of internal controls aimed at preventing the four main types of commercial corruption.

\section{[Insert Table I around here]}

In general, what is needed is a clear and known company policy regarding corruption, forming the basis for designing internal controls that address the different types of corruption. For all types of corruption, the operation of a whistleblowing line is an important control because it allows anyone who experiences or suspects corrupt practices to report them. In addition, kickbacks are mainly prevented in purchasing organizations through the proper documentation of all phases of the purchase and the segregation of duties regarding the authorization of purchases, purchasing, receipt of goods and payment. Vendors are often preapproved to avoid conflicts of interest and kickbacks and are required to sign right-to-audit clauses. The preapproval of vendors is also a primary control for avoiding bid rigging, combined with the systematic monitoring of prices, change orders, or trends in the bidding process. Conflicts of interest are mainly prevented through the segregation of duties and the preapproval of vendors. Political types of corruption, such as nepotism and favouritism, are prevented by ensuring the implementation of transparent and objective policies for evaluating individual performance and by segregating those evaluating performance from those involved in negotiating remuneration. 
While in common corporate governance frameworks it is management's duty to establish such internal controls based on the board's policies, there is a risk that this may not be done. Consequently, some independent monitoring of internal controls is needed to ensure that policies are actually known and followed, that internal controls are established and executed according to policies and that eventual breeches are appropriately sanctioned. Without such monitoring, any policy to prevent the risk of corruption will have little effect. Monitoring internal control systems has become one of the key tasks of internal auditing (Reding et al., 2013; Spira and Page, 2003) and the existence of an internal audit function is therefore an important element in the prevention of corruption. The focus of internal auditing on corruption is also important because many of the corruption schemes listed in Table I may involve management. Management is often in a position to override internal controls designed to prevent corruption and other types of fraud. Thus, particular controls preventing management overrides are needed (IFAC, 1999). This type of control is usually the responsibility of the audit committee, which should establish a whistleblowing line allowing people inside and outside the organization to report suspicions of corruption, as well as management override of internal controls. The audit committee should also develop a programme for board feedback from auditors and others regarding the risk of management fraud and the override of internal controls. This may, for instance, be done through systematic interviews with internal and external auditors and with the compensation committee (AICPA, 2016).

However, any such internal control system to prevent corruption outlined above has a major limitation: it only addresses the demand side of the corrupt transaction, which is a shortcoming in many anti-corruption programmes as the supply side is just as important (Tanzi, 1998; Wu, 2005). Recently, it has therefore been suggested that collective action, involving both the procuring organization and the vendors, is the most effective way of preventing corruption (World Bank Institute, 2008). The objective of collective action is to create a level playing field between competitors, free from corruption, to allow the most competitive bid to win. Collective action may take the form of formal contracts, called "integrity pacts", between the procuring organization and the bidding company, which includes provisions for external monitoring and imposing sanctions in the case of violations. External audit firms may monitor such anti-corruption contracts on behalf of the procuring organization. A more promising form of collective action is to establish "certifying business coalitions" (Sidhu, 2009), in which all suppliers voluntarily agree to comply with anticorruption criteria to obtain an anti-corruption certification. External audit firms audit compliance with these criteria and the certification is withdrawn in the case of non-compliance. The procuring 
organization should then require all suppliers to hold anti-corruption certification, thereby preventing corruption.

\section{How auditing may detect corruption}

The occasional detection of corruption by auditors is important because the perceived risk of getting caught is an important factor in deterring people from engaging in fraudulent behaviour, such as corruption (Wells, 2002). This is particularly the case for elected politicians, for whom the risk of detection combined with re-election incentives reduces corruption (Ferraz and Finan, 2011). Internal and external auditors should therefore consider what evidence the different types of corruption may leave and use this information in testing for corruption. For example, kickback schemes typically create overspending, which may be detected through analytical procedures such as benchmarking (Gramling et al., 2012; Wells, 2003).

In addition to documentary evidence, Zimbelman and Albrecht (2009) outline three other types of evidence that may be relevant for the detection of corruption. Testimonial evidence may be obtained from interviews with people within and outside the organization. Building on testimonial evidence, Khan (2006) suggests "participatory auditing" as a tool to detect corruption. Participatory audits involve collecting external evidence from the external users of a service, client organizations, or the general public by means of surveys and other investigative techniques. Physical evidence is also important because public procurement often involves assets that may be inspected to check their existence or valuation (i.e. quality). Accordingly, Dye and Stapenhurst (1998: 14) suggest the inspection of construction assets to detect substandard work as an example of audit work designed to detect corruption. Finally, personal observations may provide evidence concerning corruption. These may be the auditors' own observations, but they may also be observational evidence from undercover agents, as suggested by Klitgaard (2006), or from the press.

While internal auditors frequently detect corruption and other types of fraud, external auditors do so less often (ACFE, 2016). The reason for this is probably that the work of external auditors is guided by the assessment of risk and materiality and is focused on the detection of material misstatements in financial statements. If corruption is not perceived to result in material misstatements, external auditors are not likely to focus their work on detecting corruption. However, in many cases, evidence of bribery will appear in the bribe-givers' books in the form or errors or misstatements (Wells, 2003). Table II outlines the potential misstatements derived from commercial corruption and political corruption in the corruption giver's and corruption receiver's organizations. 


\section{[Insert Table II around here]}

\subsection{Detecting corruption in the giver's organization}

The most common types of commercial corruption are bribery and conflicts of interest (Wells, 2014). Such corruption schemes are likely to result in errors in the financial statements of the corruption giver's organization. There are three potential types of error which may occur: classification errors, undisclosed revenue and fictitious costs. As bribery is illegal in most countries, the organization paying bribes may reclassify the bribes as a form of legitimate cost. A bribe may, for example, be classified as a consulting fee, a commission, or payment for some intangible service (Wells, 2003). In these cases, the reclassification of the bribe will create a classification error. Correct classification means that all transactions have been recorded in the proper accounts and is an audit objective in financial audits (Eilifsen et al., 2014). To the extent that classification errors are material, financial auditors are expected to find them. When paying bribes, it is therefore more common to keep bribery payments off the books. To do so, the company paying the bribes will need to use money not accounted for, also known as "slush funds". This was, for instance, the case in the Siemens corruption scandal (Sidhu, 2009), as well as in the Hewlett-Packard bribery cases in Russia, Poland and Mexico (Sikka and Lehman, 2015). Slush funds are usually composed of the proceeds from undisclosed revenues or from payments of fictitious costs. For example, in the case of Hewlett-Packard in Russia, Sikka and Lehman (2015) report how computer hardware was sold to intermediaries and later bought back at marked-up prices, following which the payment to the intermediary ended up in Hewlett-Packard's controlled slush funds. Undisclosed revenues and fictitious costs affect two of the financial auditor's main audit objectives: completeness and existence. Completeness means that all transactions that should be recorded are in fact recorded and existence means that all transactions that have been recorded have in fact occurred. The existence and use of slush funds is therefore likely to create errors in financial statements. Furthermore, the existence of slush funds signals a low degree of management integrity and therefore represents a qualitative materiality problem for the financial auditors, regardless of the error's quantitative materiality. Low management integrity is likely considered a "significant risk" according to ISA 315 , with the consequence that the audit must be planned to test the reasonableness of all management's estimates and judgements relating to the financial statements. Thus, financial auditors have an interest in paying some attention to their clients use of bribery and this is probably the reason why Transparency International (2009: 135) points out that auditors are "best positioned 
to detect" bribery and why auditing in practice appears to reduce companies' use of bribery (Farooq and Shehata, 2018).

In addition to errors created, the payment of bribes is also likely to be prohibited by law, as is the case in many countries. Regulations such as the UK Bribery Act and the US Foreign Corrupt Practices Act have de facto extended the jurisdiction of these countries to include any third country in which multinational corporations are operating. This is of importance because ISA 250 (revised)/ISSAI 1250, as discussed earlier, require auditors to obtain audit evidence regarding compliance with laws and regulations that may result in material misstatements in the financial statements. As corruption is intentional and probably also material, the auditor is required to discuss this with "those charged with governance" (ISA 250) as soon as practicable. If this discussion does not solve the non-compliance problem, the auditor may need to report this to the appropriate authorities and if there are still material misstatements in the financial statements following the discussion, the auditor is required to express a qualified opinion or an adverse opinion.

Consequently, external financial auditors in the private and public sectors need to assess the risk that a client company might be paying bribes or engaging in other types of commercial corruption. These risks are likely to be high in cases in which the company operates in markets or regions where corruption is common. When corruption risk is considered high, the responding audit procedures should focus on the detection of reclassification errors and the potential existence of slush funds. Bribery reclassified as legitimate expenses may be detected by examining accounts for consulting fees, commissions and intangible services and comparing these expenses with the corresponding contracts. Payments going to a customer's employees or public servants in procuring functions are indications of bribery, as are contracts that are won without normal competitive tendering. Slush funds are by nature more difficult to detect. However, a high perceived risk of corruption should lead the auditor to increase the tests for revenue completeness, in particular for cash-based sales transactions, which are easy to divert to slush funds before they are registered. Other responses may be to monitor tips from whistleblowers or to undertake critical interviewing of employees, for example in accounting and sales departments, asking whether they have been asked to do something they find unethical, as suggested by Wells (2001).

Political types of corruption, such as nepotism (patrons favouring relatives), clientelism (patrons favouring individual clients) and favouritism (patrons favouring particular social groups), distort free competition because orders, jobs, or benefits are given to a related party. This type of 
corruption will most likely result in problems with economy, efficiency and effectiveness in the giver's organization because of the lack of free competition. A high risk of political corruption is therefore a matter for public sector auditors to consider when doing performance audits. However, political corruption may also result in misstatements in financial reporting. In cases in which there are transactions between a company and close relatives of the company's key management personnel, this is likely to qualify as related party transactions according to IAS $24^{9}$ and IPSAS $20^{10}$. This is, for example, the case when a company purchases goods or services from relatives at inflated prices, sells goods to relatives below market prices, or gives relatives gifts without receiving anything in return. According to IAS 24 and IPSAS 20, the nature and amount of such transactions, as well as any outstanding balances, must be disclosed in notes to the financial statements. According to ISA 550, ${ }^{11}$ the auditor should understand related party transactions and assess whether these increase the risk of material errors, an assessment that is hardly possible without awareness of the possibility of nepotism and clientelism. This line of reasoning is also reflected in the corresponding ISSAI $1550,{ }^{12}$ according to which public sector financial auditors are required to obtain evidence that transactions with third parties, including related parties, are subject to competitive tendering or other forms of market testing.

Thus, financial auditors in the public sector, in which political corruption typically occurs, should assess the risk of material errors arising from political types of corruption. When assessing such risk, it is important to note that materiality assessments in the public sector are different from those in the private sector because financial statements are used for public policy decisions that have political, social and security implications (Aggestam-Pontoppidan and Andernack, 2016: 59). Misstatements arising from political corruption are therefore likely to be considered qualitatively material, even when the monetary errors are immaterial. When there is a risk of material errors due to political corruption, the financial auditor should therefore design audit procedures that address this risk. Such audit procedures are likely to focus on whether normal business procedures have been followed, for example whether contracts are awarded in a normal competitive tendering process.

\subsection{Detecting corruption in the receiver's organization}

The receiver of bribery or other types of commercial corruption is usually an individual who is not to demonstrate accountability using financial statements. However, this individual usually receives 
the bribe because he/she is abusing a position within an organization for private benefit and the corrupt act will therefore affect the financial statements of this organization.

For a private sector organization, when someone is the recipient of bribery, it will likely result in excessive purchases of goods and services, purchases above the market price, and/or delivery of substandard quality (Wells, 2003). In the case of material goods, this will likely increase the inventory and create valuation errors because inventory is normally carried at the lower of historical cost and net realizable value according to IAS $2 .{ }^{13}$ As the cost is likely to be above the market price when bribes are received, inventory valuation is likely to be too high. When the external auditor assesses there is a risk of someone in the procuring function receiving bribery, the appropriate response should be to implement audit procedures focusing on detecting problems with the valuation of the assets. Such procedures may include intensified inspection of assets to detect delivery of substandard quality, analytical procedures focusing on the development of costs and quantity in stock for individual inventory items and inventory aging. Bribes in relation to the purchase of immaterial services, however, are less likely to leave errors in the financial statements. This type of bribery may be detected by examining the nature of entries in accounts for services procured, by checking whether normal competitive tendering has taken place regarding the purchase and through inquiry regarding the service at the management level above the person authorizing the procurement of the service. Furthermore, Krambia-Kapardis (2016) suggests that an assessed risk of corruption should lead the auditor to be more sceptical and to "audit outside the books", for instance by comparing employees' or managers' lifestyles with their income.

In a public sector organization, when someone receives bribes, it will cause problems with the valuation of assets similar to those in the private sector, which is a concern for public sector financial auditors. In addition, it will also cause problems with the organization's economy, efficiency and effectiveness and commercial corruption is therefore also a concern for performance auditors, such as SAIs or public sector internal auditors. Corruption in the public procurement process may result in economy problems, such as budget overruns, costs above market prices, the cancelling of competitive bidding, adding costs after competitive contracts are awarded, stripping of public assets and lack of accountability for overspending (Otalor and Eiya, 2013). It may also result in efficiency problems, such as huge idle capacity, disproportionately high expenditure on maintenance, neglect of maintenance of particular assets while directing funds to similar/replacement assets, poor quality of construction work, etc., repeated extensions given to 
contractors, repeated changes in orders and repeated changes in staffing to avoid oversight and institutional memory (Otalor and Eiya, 2013). Finally, corruption may result in effectiveness problems, such as a lack of quantifiable and measurable performance indicators, public dissatisfaction with services, services that are not delivered as planned, a lack of mechanisms for complaining about services and senior management being unavailable or not attentive to complaints about services (Otalor and Eiya, 2013). Thus, corruption in the procurement process is likely to create many problems, which performance auditors may detect using benchmarking techniques, by inspection of assets, by public service satisfaction surveys, as well as through establishing whistleblower lines.

For an organization in which someone is the recipient of political corruption, it is less likely to cause financial statement errors because the receiver is usually an individual or a social group who is not accountable using financial statements. For instance, a typical case of nepotism is the recruitment of a less competent relative for a position in a public sector organization. While this will not cause financial statement errors, it is likely to result in economy and efficiency problems, which is a focus area for performance auditors and may be detected by checking whether the organization has complied with normal competitive recruitment procedures. Cases of favouritism may be more difficult to detect at the receiving end. A typical case might be that a public contract is given to a company with ties to government. In such a case, the receiver of the political favour is likely to appear more successful than its competitors. When undertaking the analytical procedures required by ISA 240/ISSAI 1240 as part of the fraud risk assessment for a company, external auditors may identify such successful companies by benchmarking them against direct competitors or industry norms. A further benchmarking of prices against competitors' prices may reveal cases in which there is no competitive reason for the company's apparent success. Unlike commercial corruption, political types of corruption leave less evidence of return favours for the auditor to follow. For instance, the return favours from the receivers of nepotism, clientelism or favouritism are often of an immaterial nature, being in the form of political or cooperative support. However, occasionally the return favours may be of a monetary nature, for example in the form of political campaign contributions, and in these cases the financial or the performance auditor may check the legality of these contributions. 


\section{Conclusion}

The literature on auditing and corruption analysed in this paper is primarily focused on the micro level of firms and organisations, thus supplementing the macro level of analysis often found in works on corruption within political science and sociology. The result of this analysis is that private sector financial auditing has generally neglected corruption as a potential source of material errors in financial statements, while public sector auditing has, to some degree, accepted responsibility for the prevention of corruption. The paper has examined the arguments for the limited role of auditing in the fight against corruption. The main arguments are that corruption leaves no errors in the financial statements and leaves no evidence for the auditor to examine. This paper refutes these arguments, arguing that commercial corruption creates misstatements in the financial statements, while political corruption creates problems with the three performance audit objectives of efficiency, effectiveness and economy. Because of their fraudulent nature, such misstatements are likely to be considered material by users of financial statements, regardless of the amount.

As argued by Dye and Stapenhurst (1998), auditing is one of the eight pillars of integrity. Thus, auditing alone cannot curb corruption, but it is an important part of combined efforts against corruption. Because of the scope of auditing in the present "audit society" (Power, 1997), auditing may have the potential to change agents' beliefs about what other agents do in relation to corruption, which is what Rothstein (2011) argues is pivotal in creating change. At best, auditing can make it visible that corruption is not the norm in organizations, thus depriving agents of the rationalization that corruption is acceptable because "everyone does it". In worst case, auditing may make it visible that endemic corruption is the norm, thus hopefully forcing governments, international institutions and business to act against it.

The findings in this paper therefore have a number of important implications for practice. First, financial auditors are required to find material misstatements in the financial statements and as corruption creates such misstatements, it is fair to expect auditors to accept the responsibility for preventing and detecting corruption. The implication of this is that ISA 240 and the corresponding public sector standard ISSAI 1240 explicitly need to include corruption as a main category of fraud, one which the auditor should consider in the initial risk assessment. Public sector auditors also need the formal authority to detect corruption and/or to collaborate with other investigative agencies. Second, corruption always involves a giver and a receiver, but creates different types of errors in the giving and receiving organizations. A typical bribery case, in which a private company bribes 
someone in a public sector organization, creates financial statement errors in the private company and problems with economy, efficiency and effectiveness in the public sector organization. Thus, to fight corruption effectively, auditors need to address both ends and this requires collaboration between private and public sector auditors. However, such collaboration is generally hampered by regulation governing professional secrecy and this needs to be addressed, for instance by giving private sector auditors a legislative duty to report to the relevant public sector auditors in the case that they find their client is involved in corruption. Third, auditors need to develop better techniques for detecting corruption. Such techniques will inevitably involve more reliance on external evidence to assess the risk of corruption. Evidence may come from collaboration with other types of auditors, from the operation of whistleblower lines encouraging and perhaps rewarding successful tips regarding corruption and from collaboration with the press. When auditors assess there is an increased risk of material errors due to corruption, audit procedures will need to be designed to address this risk. Such procedures will likely include substantially more physical examination of assets. Fourth, preventive measures against corruption need to focus on the system of corruption, not the individual entity. To design preventive measures, organizations and auditors need to understand how corrupt buyers and sellers are found and matched, how each side benefits from the corrupt transaction, how they make and enforce contracts and not least what evidence is left by the corrupt transaction (Klitgaard, 2006). The collective actions reported by Sidhu (2009), in particular anti-corruption certifications, appear to be a very promising way of combatting corruption in the procurement process and have the potential to become an important new service for the auditing profession.

As argued in this paper, the link between corruption and auditing is little researched and thus provides ample opportunities for further research. An obvious opportunity is to explore whether there is a general expectation gap between private/public sector users of financial statements and auditors in relation to their potential role in preventing, detecting and reporting corruption. Public reactions to corruption scandals, such as the FIFA scandal (Browning, 2015), certainly give reason to believe this. The apparent exclusion of corruption from auditing standards points to the "deficient standards" explanation (Porter, 1993) for the expectation gap and thus emphasizes the need for critical studies of audit standard setting questioning the rationale behind this. Another research opportunity follows from the finding that corruption is often institutionalised; it has become a norm and expectation in political and social life. In these cases, "actors have a way they view the world, and, unless some event of major proportions occurs that unambiguously changes their world, they 
will continue to act in a consistent fashion" as Fligstein (1991: 316) puts it. This is the reason why Rothstein (2011) suggests that to reduce corruption revolutionary change in institutions is needed. There is a research opportunity in exploring whether accounting or auditing may contribute to create such events of major proportions that unambiguously changes people's world view. Alternatively, research in accounting's role in breaking institutionalised corruption may be informed by later developments in institutional theory, in particular the works on institutional entrepreneurship (e.g. Battilana et al., 2009). Finally, the paper's conclusion concerning auditors' reluctance to detect corruption also raises an interesting question for future research. There is a growing body of literature based on the theory of Abbott (1988), which analyses how auditors actively seek to include new areas of work in the jurisdiction of auditing, usually in fierce competition with other professions (see e.g. Arena and Jeppesen, 2010; Evans and Honold, 2007; Jeppesen, 2012). Auditing is defined as checking compliance with established criteria (American Accounting Association, 1973), so if acknowledged criteria for universal and impartial practices in public sector organizations can be established, corruption work can become part of the audit jurisdiction. Thus, the auditing profession has business incentives to include corruption in the jurisdiction yet seems to be very little interested in this work. The jurisdiction of corruption audit is vacant and an analysis of why this is the case may provide a significant contribution to the sociology of professions, as well as to the fight against corruption.

However, there are recent indications that IFAC is starting to take corruption more seriously. At IFAC's World Congress of Accountants 2014 in Rome, Pope Francis invited the leaders of the accounting profession to meet him in the Vatican. At this meeting, the Pope called for the accounting profession to "do more to be a positive force in the fight against fraud and corruption" (IFAC, 2016a) and this call apparently prompted IFAC to act. Thus, in IFAC's reply to the Pope, it states three main efforts that IFAC "believe will have a lasting impact in reducing both the supply and demand sides of fraud and corruption" (IFAC, 2016a). First, IFAC has accelerated its efforts to increase the professional accounting capacity in developing countries. Second, IFAC is working with the G20 and the Organisation for Economic Co-operation and Development (OECD) to strengthen governance. This includes the recent revision of IFAC's Code of Ethics (IESBA, 2016) to include provisions for accountants in business to address issues of non-compliance with laws and regulations such as corruption, if necessary, by reporting this to the appropriate authorities. It also includes intensified collaboration at the local level, an example being that IFAC and the Law Society in the UK have resolved to fight corruption (IFAC, 2016b). Third, IFAC has intensified its 
promotion of IPSAS through the establishment of the organization "Accountability. Now"14 to develop greater transparency in government accounting. Thus, what appears to be IFAC's present policy regarding corruption is stated in a press release by IFAC: “Transparency, accountability, and serving the public interest motivate our ongoing support for global reporting standards and ethical behavior. These standards underpin the profession's role in detection of fraud, corruption and bribery - and strengthen organizations to assist in prevention" (IFAC, 2016c). This emphasis on the profession's role in the detection of corruption and bribery is new and IFAC has yet to deliver in terms of incorporating this standpoint in its International Standards on Auditing and Code of Ethics. There is a role for critical research in monitoring whether IFAC will eventually "walk the talk", but the role of auditing in the fight against corruption may well become more proactive in the future.

\section{Acknowledgements}

This study is part of a four-year comparative project on the influence of performance auditing on politics and public administration in the Nordic countries. The project is funded by a research grant from the Joint Committee for Nordic Research Councils in the Humanities and Social Sciences (NOS-HS), project number 219574. 


\section{References}

Abbott, A. (1988). The System of Professions: An Essay on the Division of Expert Labor, Chicago: University of Chicago Press.

ACFE (2016). Report to the nations on occupational fraud and abuse, available at: http://www.acfe.com/rttn2016.aspx. Accessed 18.10.16.

Aggestam-Pontoppidan, C., Andernack, I. (2016). Interpretation and Application of IPSAS, Chichester: Wiley.

AICPA (2016). Management Override of Internal Control: The Achilles' Heel of Fraud Prevention, New York: The American Institute of Certified Public Accountants.

American Accounting Association (1973). A Statement of Basic Auditing Concepts, Sarasota Fl.: American Accounting Association.

Arena, M., Jeppesen, K.K. (2010). The jurisdiction of internal auditing and the quest for professionalization: the Danish case. International Journal of Auditing, 14(2), 111-129.

Arens, A.A., Elder, R.J., Beasley, M.S. (2014). Auditing and Assurance Services, Global Edition, 15/E, Pearson.

Bakre, O.M. (2007). The unethical practices of accountants and auditors and the compromising stance of professional bodies in the corporate world: Evidence from corporate Nigeria, Accounting Forum, 31(3), 277-303.

Battilana, J., Leca, B., Boxenbaum, E. (2009). How actors change institutions: towards a theory of institutional entrepreneurship, The Academy of Management Annals, 3(1), 65-107.

Bierstaker, J.L. (2009). Differences in attitudes about fraud and corruption across cultures: theory, examples and recommendations, Cross Cultural Management, 16(3), 241-250.

Borge, M. (1999). The role of supreme audit institutions (SAIs) in combating corruption. Paper presented at the $9^{\text {th }}$ International Anti-Corruption Conference, Durban, October 1999.

Brief, R.P. (1977). The Accountant's Responsibility for Disclosing Bribery: A Historical Note. The Accounting Historians Journal, 4(2), 97-100.

Browning, L. (2015). Corruption in FIFA? Its auditors saw none. The New York Times, June 5, available at: http://www.nytimes.com/2015/06/06/sports/soccer/as-fifa-scandal-grows-focusturns-to-its-auditors.html?_r=1 . Accessed 26.05.16.

Cascarino, R.E. (2012). Corporate Fraud and Internal Control: A Framework for Prevention, Hoboken: John Wiley \& Sons.

Chowdhury, R., Innes, J. (1998). A qualitative analysis of the audit expectations gap in the public sector of Bangladesh. International Journal of Auditing, 2(3), 247-261. 
COSO (2004). Enterprise Risk Management - Integrated framework. Executive Summary, available at: www.coso.org/documents/coso_erm_executivesummary.pdf Accessed 18.10.16.

Davies, M., Aston, J. (2011). Auditing Fundamentals, Harlow: FT Prentice Hall.

Dye, K.M., Stapenhurst, R. (1998). Pillars of Integrity: The Importance of Supreme Audit Institutions in Curbing Corruption, Economic Development Institute of the World Bank, available at: http://documents.worldbank.org/curated/en/199721468739213038/Pillars-ofintegrity-the-importance-of-Supreme-Audit-Institutions-in-curbing-corruption Accessed 04.11.16.

ECIIA (1999). The Internal Auditor's Role in the Prevention of Fraud, Position paper, Brussels: European Confederation of Institutes of Internal Auditors.

Eilifsen, A., Messier, W.F., Glover, S.M., Prawitt, D.F. (2014). Auditing and Assurance Services, 3rd international ed., London: McGraw-Hill.

Evans, L., Honold, K. (2007). The division of expert labour in the European audit market: the case of Germany, Critical Perspectives on Accounting, 18(1), 61-88.

Everett, J., Neu, D., Rahaman, A.S. (2007). Accounting and the global fight against corruption, Accounting, Organizations and Society, 32(6), 513-542.

Farooq, O., Shehata, N.F. (2018). Does external auditing combat corruption? Evidence from private firms, Managerial Auditing Journal, 33(3), 267-287.

Ferraz, C., Finan, F. (2011).Electoral accountability and corruption: evidence from the audits of local governments, The American Economic Review, 101(4), 1274-1311.

Fligstein, N. (1991). The Structural Transformation of American Industry: An Institutional Account of the Causes of Diversification, 1919-1979, in Powell \& DiMaggio (ed) The New Institutionalism in Organizational Analysis, Chicago: The University of Chicago Press.

Gramling, A.A., Rittenberg, L.E., Johnstone, K.M. (2012). Auditing, 8th international ed., London: South-Western Cengage Learning.

Gray, I., Manson, S. (2008). The Audit Process. Principles, Practice and Cases, 4th ed., London: South-Western Cengage Learning.

Gustavson, M., Sundström, A. (2016). Organizing the audit society: does good auditing generate less public sector corruption?, Administration \& Society, doi:10.1177/0095399716674306.

Hayes, R.S., Dassen, R., Schilder, A., Wallage, P. (2005). Principles of Auditing: An Introduction to International Standards on Auditing, 2nd ed., Harlow: Financial Times Prentice Hall.

IESBA (2016). Responding to non-compliance with laws and regulations, available at: http://www.ifac.org/publications-resources/responding-non-compliance-laws-and-regulations Accessed 04.11.16. 
IFAC (1999). The Accountancy Profession and the Fight against Corruption, discussion paper, available at:

https://web.archive.org/web/19991127080028/http://www.ifac.org/Council/AntiCorruptionPap er.html Accessed 28.10.16.

IFAC (2016a). The accountancy profession: fighting fraud and corruption, press release, available at: http://www.ifac.org/publications-resources/accountancy-profession-fighting-fraud-andcorruption Accessed 18.11.16.

IFAC (2016b). Accountants, lawyers resolve to fight corruption, press release, available at: https://www.ifac.org/news-events/2016-05/accountants-lawyers-resolve-fight-corruption Accessed 03.06.16.

IFAC (2016c). Strong international standards, governance \& ethics help fight bribery, press release, available at: https://www.ifac.org/news-events/2016-03/strong-international-standardsgovernance-ethics-help-fight-bribery Accessed 03.06.16.

IMF (2016). Corruption: Costs and Mitigating Strategies. IMF Staff Discussion Note SDN/16/05, available at: https://www.imf.org/external/pubs/ft/sdn/2016/sdn1605.pdf. Accessed 11.04.18.

INTOSAI (2013). ISSAI 5700 guidelines for the audit of corruption prevention in government agencies, Exposure Draft, available at: www.issai.org Accessed 12.10.15.

Jancsics, D. (2014). Interdisciplinary perspectives on corruption, Sociology Compass, 8(4), 358372.

Jávor, I., Jancsics, D. (2016).The role of power in organizational corruption: an empirical study, Administration \& Society, 48(5), 527-558.

Jeppesen, K.K. (2012). Jurisdictional competition between private and public sector auditors: the case of the Danish public sector auditor qualification, Financial Accountability \& Management, 28(2), 215-246.

Johnston, M. (1996). The search for definitions: the vitality of politics and the issue of corruption, International Social Science Journal, 48(149), 321-335.

Kassem, R., Higson, A.W. (2016). External Auditors and Corporate Corruption: Implications for External Audit Regulators, Current Issues in Auditing, 10(1), 1-10.

Khalil, S., Saffar, W., Trabelsi, S. (2015). Disclosure Standards, Auditing Infrastructure, and Bribery Mitigation, Journal of Business Ethics, 132, 379-399.

Khan, M.A. (2006). Role of audit in fighting corruption, Paper for UN Ad Hoc Group Meeting on "Ethics, Integrity, and Accountability in the Public Sector: Re-building Public Trust in Government through the Implementation of the UN Convention against Corruption", St. Petersburg, Russia. Available at: 
http://unpan1.un.org/intradoc/groups/public/documents/UN/UNPAN025122.pdf Accessed 04.11.16.

Kimbro, M.B. (2002). A cross-country empirical investigation of corruption and its relationship to economic, cultural, and monitoring institutions: an examination of the role of accounting and financial statements quality, Journal of Accounting, Auditing \& Finance, 17(4), 325-350.

Klitgaard, R. (2006). Introduction: subverting corruption, Global Crime, 7(3-4), 299-307.

Krambia-Kapardis, M. (2016). Corporate Fraud and Corruption: A Holistic Approach to Preventing Financial Crises, New York: Palgrave Macmillan.

Labuschagne, H., Els, G. (2006). Corruption and fraud: any lessons for the auditor?, Meditari Accountancy Research, 14(1), 29-47.

Liu, J., Lin, B. (2012). Government auditing and corruption control: evidence from China's provincial panel data, China Journal of Accounting Research, 5(2), 163-186.

Malagueño, R., Albrecht, C., Ainge, C., Stephens, N. (2010). Accounting and corruption: a crosscountry analysis, Journal of Money Laundering Control, 13(4), 372-393.

Mennicken, A. (2010). From inspection to auditing: audit and markets as linked ecologies, Accounting, Organizations and Society, 35(3), 334-359.

Neu, D., Everett, J., Rahaman, A.S., Martinez, D. (2013). Accounting and networks of corruption, Accounting, Organizations and Society, 38(6), 505-524.

Neu, D., Everett, J., Rahaman, A.S. (2014). Preventing corruption within government procurement: constructing the disciplined and ethical subject, Critical Perspectives on Accounting, 28(May), 49-61.

Okike, E. (2004). Management of crisis: the response of the auditing profession in Nigeria to the challenge to its legitimacy, Accounting, Auditing \& Accountability Journal, 17(5), 705-730.

Otalor, J.I., Eiya, O. (2013). Combating corruption in Nigeria: the role of the public sector auditor, Research Journal of Finance and Accounting, 4(4), 122-131.

Porter, B. (1993). An empirical study of the audit expectation-performance gap, Accounting and Business Research, 23(93), 49-68.

Power, M. (1997). The Audit Society: Rituals of Verification, Oxford: Oxford University Press.

Reding, K., Sobel, P.J., Anderson, U.L., Head, M.J., Ramamoorti, S., Salamasick, M., Riddle, C. (2013). Internal Auditing: Assurance \& Advisory Services, 3rd ed., Altamonte Springs: The Institute of Internal Auditors Research Foundation.

Roberts, J. (2015). The 'subject' of corruption, Critical Perspectives on Accounting, 28(May), 8288. 
Rothstein, B. (2011). Anti-corruption: the indirect 'big bang' approach, Review of International Political Economy, 18(2), 228-250.

Rothstein, B., \& Varraich, A. (2017). Making Sense of Corruption. Cambridge: Cambridge University Press.

Shihata, I.F. (1997). Corruption: a general review with an emphasis on the role of the World Bank, Journal of Financial Crime, 5(1), 12-29.

Sidhu, K. (2009). Anti-corruption compliance standards in the aftermath of the Siemens scandal, German Law Journal, 10(8), 1343-1354.

Sikka, P., Lehman, G. (2015). The supply-side of corruption and limits to preventing corruption within government procurement and constructing ethical subjects, Critical Perspectives on Accounting, 28(May), 62-70.

Soltani, B. (2007). Auditing: An International Approach, Harlow: Pearson Education.

Spira, L., Page, M. (2003). Risk management: the reinvention of internal control and the changing role of internal audit, Accounting, Auditing \& Accountability Journal, 16(4), 640-661.

Tanzi, V. (1998). Corruption around the world: causes, consequences, scope, and cures, IMF Staff Papers, 45(4), 559-594.

Thomson, S. (2017). We waste $\$ 2$ trillion a year on corruption. Here are four better ways to spend that money. Available at https://www.weforum.org/agenda/2017/01/we-waste-2-trillion-a-yearon-corruption-here-are-four-better-ways-to-spend-that-money. Accessed 11.04.18.

Transparency International (2009). Global Corruption Report 2009: Corruption and the Private Sector, Cambridge: Cambridge University Press.

Wells, J.T. (2001). 'Why ask?' You ask, Journal of Accountancy, 192(3), 88-93.

Wells, J.T. (2002). Let them know someone's watching, Journal of Accountancy, 193(5), 106-110.

Wells, J.T. (2003). Corruption: causes and cures, Journal of Accountancy, 195(4), 49-52.

Wells, J.T. (2014). Principles of Fraud Examination, 4th ed., Hoboken: John Wiley \& Sons Inc.

World Bank Institute (2008). Fighting Corruption through Collective Action, World Bank Institute.

Wu, X. (2005). Firm accounting practices, accounting reform and corruption in Asia, Policy and Society, 24(3), 53-78.

Zimbelman, M.F., Albrecht, C.C. (2009). Forensic Accounting, 4th ed., South-Western Cengage Learning. 


\footnotetext{
${ }^{1}$ The World Economic Forum is the international organization for public-private cooperation, see https://www.weforum.org/about/world-economic-forum.

${ }^{2}$ The international football association Fédération Internationale de Football Association. Over recent decades, the FIFA leadership has repeatedly been accused of corruption, bribery, vote-rigging, money laundering, wire fraud and racketeering. For an overview and references, see https://en.wikipedia.org/wiki/2015_FIFA_corruption_case

${ }^{3}$ The eight pillars are: political will, administrative reforms, watchdog agencies, parliament, public awareness, the judiciary, the media and the private sector (Dye and Stapenhurst, 1998).

${ }^{4}$ International Standard on Auditing 240: The Auditors' Responsibility Relating to Fraud in an Audit of Financial Statements. The ISA are developed by the International Auditing and Assurance Standards Board (IAASB) under the International Federation of Accountants (IFAC).

${ }^{5}$ International Standards for Supreme Audit Institutions 1240: The Auditors' Responsibility Relating to Fraud in an Audit of Financial Statements. The ISSAI concerning financial auditing are essentially ISA with additional comments on how to apply the standard in a public sector setting. The ISSAI are developed by the International Organization of Supreme Audit Institutions (INTOSAI).

${ }^{6}$ ISA 250 (Revised): Consideration of Laws and Regulations in an Audit of Financial Statements. The standard was revised in October 2016.

${ }^{7} \mathrm{http} / / / \mathrm{www}$.business.dk/foedevarer/carlsberg-betaler-smaabestikkelse

${ }^{8} \mathrm{http}: / / \mathrm{www}$.business.dk/foedevarer/carlsberg-goer-op-med-lang-tradition-for-smoerelse

${ }^{9}$ International Accounting Standard 24: Related party disclosures

${ }^{10}$ International Public Sector Accounting Standard 20: Related party disclosures

${ }^{11}$ International Standard on Auditing 550: Related parties

${ }^{12}$ International Standard for Supreme Audit Institutions 1550: Related parties

${ }^{13}$ International Accounting Standard 2: Inventories

${ }^{14} \mathrm{https}: / / \mathrm{www}$. ifac.org/about-ifac/accountability-now
} 
Table I.

Preventive internal controls

Type of corruption $\quad$ Examples of preventive internal controls

\begin{tabular}{|c|c|}
\hline Kickbacks & $\begin{array}{l}\text { - Written policies prohibiting employees from soliciting or accepting any gift } \\
\text { or favour from a customer or a supplier } \\
\text { - Written policies regarding proper documentation of all purchases, including } \\
\text { name of person who initiated, approved and received the purchase } \\
\text { - Independent internal or external review of buying patterns } \\
\text { - Requirement that all vendors sign contracts with "right-to-audit" clauses } \\
\text { - Segregation of purchasing, authorization, receiving and storing goods, cash } \\
\text { disbursements } \\
\text { - Matching potential vendors against an updated list of approved vendors } \\
\text { - Proper review and matching of all support in disbursement vouchers } \\
\text { - Establishment of well-articulated, measurable and quantified performance } \\
\text { indicators (see e.g. Otalor and Eiya, 2013) }\end{array}$ \\
\hline Bid rigging & $\begin{array}{l}\text { - Most controls listed under "Kickbacks" are relevant here, in particular: } \\
\text { right-to-audit clauses, written policies regarding proper documentation of } \\
\text { all purchases, segregation of duties, establishment of performance } \\
\text { indicators } \\
\text { - Pre-approval procedures for all bidders } \\
\text { - Approval procedures for change orders or amendments to contracts } \\
\text { - Independent monitoring of price trends on individual items } \\
\text { - Independent investigation of significant price variations between bidders } \\
\text { - Independent investigation of purchases just below the bidding threshold } \\
\text { - Whistleblower lines }\end{array}$ \\
\hline Conflicts of interest & $\begin{array}{l}\text { - Written policies explicitly outlining what constitutes an unacceptable } \\
\text { - } \text { Senflict of interest or an improper relationship } \\
\text { disbursements } \\
\text { - Preapproval of vendors } \\
\text { - Whistleblower lines }\end{array}$ \\
\hline Illegal gratuities & $\begin{array}{l}\text { - Written policies prohibiting employees from soliciting or accepting any gift } \\
\text { or favour from a customer or a supplier } \\
\text { - Whistleblower lines }\end{array}$ \\
\hline Nepotism and favouritism & $\begin{array}{l}\text { - Written policies explicitly outlining what constitutes an unacceptable } \\
\text { conflict of interest or an improper relationship } \\
\text { - Transparent and objective policies for evaluating individual performance } \\
\text { - Segregation of performance evaluation and salary review } \\
\text { - An incentive system that align a supervisor's interests with the } \\
\text { organization's interests } \\
\text { - Whistleblower lines }\end{array}$ \\
\hline
\end{tabular}

Source: Wells (2014) Chapter 10; Cascarino (2012) Chapter 5. 
Table II.

Misstatements in financial statements resulting from different types of corruption

\section{Corruption giver's organization Corruption receiver's} organization

\section{Commercial corruption:}

Kickbacks, bid rigging, conflicts of interest, illegal gratuities, economic extortion

\section{Political corruption:}

Nepotism, clientelism, favouritism
- Classification errors

- Undisclosed revenue

- Fictitious costs

- Non-compliance with regulation
- Inventory valuation errors

- Problems with economy, efficiency, and effectiveness
- Problems with economy, efficiency, and effectiveness

- Undisclosed related party transactions

- Undisclosed gifts

- Non-compliance with regulation
- No financial statement errors at organizational level

- Political acceptance of corruption within organization causing problems with economy, efficiency, and effectiveness

- Non-compliance with regulation 